\title{
Climatic effects on breeding seabirds of the northern Japan Sea
}

\author{
Yutaka Watanuki ${ }^{1, *}$, Motohiro Ito ${ }^{1,2}$ \\ ${ }^{1}$ Graduate School of Fisheries Sciences, Hokkaido University, Minato-cho 3-1-1, Hakodate 041-8611, Japan \\ ${ }^{2}$ Present address: National Institute of Polar Research, 10-3 Midoricho, Tachikawa, Tokyo 190-8518, Japan
}

\begin{abstract}
Seabirds as marine top predators have been put forth as reliable indicators of ecosystem change. To understand climate-ecosystem change in the northern Japan Sea, we studied the timing of breeding, chick diets, and breeding success of 3 seabird species almost continuously over 26 yr on Teuri Island, 1984 through 2009. Key climate drivers in this region are: (1) westerly winter winds that cool the atmosphere and the ocean and (2) the northward flowing Tsushima Current (TC) that warms the ocean in late spring and summer. Chick diet showed decadal changes in coastal pelagic fish, with a switch from sardine Sardinops melanostictus to anchovy Engraulis japonicus in the late 1980s corresponding to intensification of the TC. There were no long-term trends in the timing of breeding or breeding success of rhinoceros auklet Cerorhinca monocerata and Japanese cormorant Phalacrocorax filamentosus, but these variables were affected by interannual variation in spring air and sea temperatures, as well as the timing of TC warm water intrusions within the foraging range $(\sim 60 \mathrm{~km}$ from the colony) of the birds. Effects include: (1) freezing of the breeding grounds by winter winds limiting access to nesting grounds and (2) availability of anchovy and sandlance Ammodytes personatus affecting chick diet, growth, and breeding success. We did not detect relationships between chlorophyll a concentrations and the availability of prey species. The timing and success of black-tailed gulls Larus crassirostris, which fed mainly on sandlance, however, could not be explained by these factors. Our study indicates potential links between the Pacific Decadal Oscillation index and the flow rate of the TC, and between the Arctic Oscillation index and local wind stress, and suggests that broad-scale atmospheric pressure fields influence local weather, oceanography, and seabirds indirectly through changes in prey availability.
\end{abstract}

KEY WORDS: Auklet · Breeding performance $\cdot$ Chick diet $\cdot$ Cormorant $\cdot$ Gull $\cdot$ Prey availability Regime shift · Timing of breeding

\section{INTRODUCTION}

Changes in wind stress (Aebischer et al. 1990), seaice extent (Loeb et al. 1997), sea-surface temperature (SST; Bertram et al. 2001, Frederiksen et al. 2006), and upwelling (Thayer \& Sydeman 2007, Schroeder et al. 2009) affect the foraging and breeding of seabirds through changes in food web structure. In addition to these 'bottom-up' effects, changes in seasonal and spatial patterns of prey influences seabird diet and breeding performance (Durant et al. 2005, Grémillet et al. 2008). Adverse local weather (low air temperature, heavy rain or snow, or strong winds) may limit accessibility to nesting grounds (reviewed by Schreiber 2002). Thus, various mechanisms may underlie the responses of seabirds to climate variability and change.

To understand climatic drivers of marine ecosystem change, it is necessary to examine how seabird diet and breeding performance varies with climatic fac- 
tors on multiple spatial and temporal scales. Seabirds may respond to climate fluctuations on immediate to interannual (Gaston et al. 2009, Moe et al. 2009), decadal (regime shift) (Anderson \& Piatt 1999, Durant et al. 2004), and long-term (ocean warming) (Jenouvrier et al. 2009) scales. Responses may also vary between regions (Frederiksen et al. 2007), depending on regional geography, marine physics, and ecosystems, and vary between species depending on the species-specific constraints (Furness \& Tasker 2000). Thus, long-term information from multiple species in multiple regions is useful for testing mechanisms.

The Japan Sea lies between the Eurasian continent and Japan (Fig. 1). Here, increases in air temperature (www.data.kishou.go.jp/climate/cpdinfo/temp/an_jpn) and SST (Yeh et al. 2010) have been reported and related to global climate change. In addition, the warm Tsushima Current (TC) heats the sea during the late spring and summer, while westerly winds cool the ocean in winter (Hase et al. 1999, Chiba \& Saino 2003). These latter factors vary at 2 time scales. (1) A decadal change in the surface air pressure in Siberia has influenced wind stress and SST; the SST was lower between the late 1970s and late 1980s and has been higher since then (Minobe et al. 2004, Yeh et al. 2010). This climatic regime shift induced a change in phytoplankton and zooplankton (Chiba \& Saino 2003, Chiba et al. 2005), as well as pelagic fish communities (Tian et al. 2008). (2) Annual changes in SST are related to air pressure anomalies in the northwestern Pacific represented by variation of the

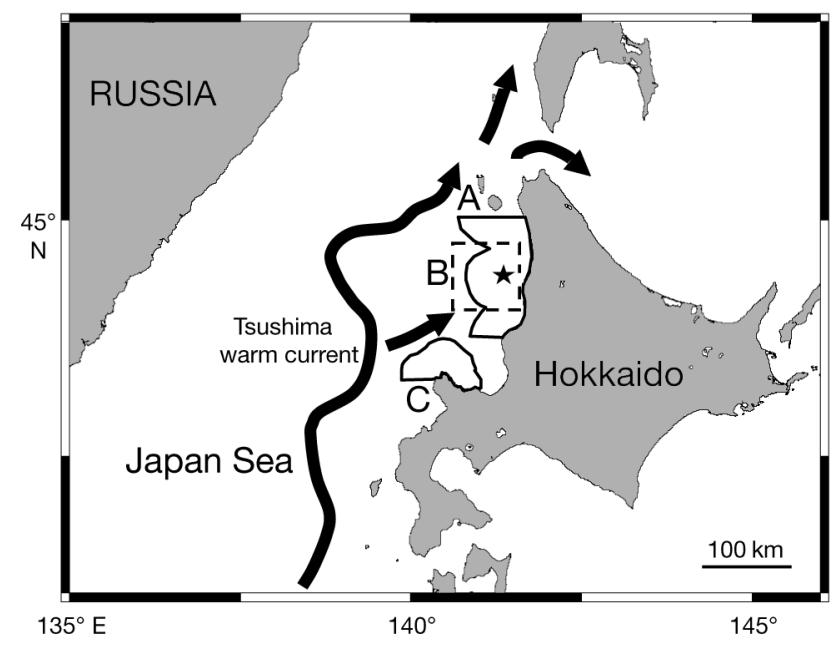

Fig. 1. Study area. $\star=$ Teuri Island. Around the colony, we measured local sea-surface temperature (SST) in Area A $(60 \times 150 \mathrm{~km})$, chlorophyll $a$ in Area B, and SST for determining the date of warm water arrival (WWA) within foraging range of rhinoceros auklets (Area C)
Aleutian Low, which drives the warm TC northward, from the Tsushima Strait in the southern Japan Sea (Minobe et al. 2004).

To understand the relationships between local and large-scale climate fluctuations and seabird biology in the Japan Sea we studied the chick diets and breeding performance of Cerorhinca monocerata (rhinoceros auklets, RHAU), Phalacrocorax filamentosus (Japanese cormorants, JCOM), and Larus crassirostris (black-tailed gulls, BTGL) on Teuri Island (Fig. 1) over 26 yr, 1984 through 2009. We examined long-term trends and the effects of interannual variation in air temperature, SST, other local climate factors, and prey availability on the timing of breeding, chick diets, and breeding success. We discuss how these local factors are influenced by broad-scale climate change.

\section{MATERIALS AND METHODS}

\section{Study area and species}

We conducted our study on Teuri Island $\left(44^{\circ} 25^{\prime} \mathrm{N}\right.$, $\left.141^{\circ} 52^{\prime} \mathrm{E}\right)$. Data were collected in 1984, 1985, and 1987, and from 1992 to 2009 ( $\mathrm{n}=21 \mathrm{yr}$ ). Additional data on the breeding of BTGL were collected in 1980. Table 1 summarizes the breeding biology and chick diets of the 3 studied species. The population sizes varied from year to year. RHAU feed on sandlance Ammodytes personatus, juvenile Japan Sea greenling Pleurogrammus azonus, and krill Thysanoessa longipes and $T$. inermis in spring (Ito et al. 2009) and on sandlance, sardine Sardinops melanostictus, and anchovy Engraulis japonicus in summer. JCOM feed on benthic fish in spring (M. Ito unpubl. data) and on epipelagic fish (sandlance and anchovy), benthic rock fish Sebastes spp., flat fish (Pleuronectiformes), and epibenthic greenlings in summer. BTGL feed on krill $T$. inermis and fish in spring (Tomita et al. 2009) and mainly on sandlance in summer. All 3 species spend winter around the Japan archipelago.

\section{Study plots and breeding biology}

RHAU nest in burrows 1 to 2 m deep on cliff shoulder slopes. JCOM nest on cliff ledges and rock stacks, and BTGL on glassy slopes. A single RHAU study plot (ca. $20 \times 50 \mathrm{~m}$ ) containing $\sim 1000$ burrows was set-up on a gentle slope in 1984. To increase the number of JCOM samples while minimizing plot size 
Table 1. Cerorhinca monocerata, Phalacrocorax filamentosus, Larus crassirostris. Total number of nests, body mass, foraging pattern, and foraging range in rhinoceros auklets (RHAU) Japanese cormorants (JCOM) and black-tailed gulls (BTGL). Range of the annual mean values of the mass proportion of fish prey in chick diet, the timing of breeding (hatching date for RHAU, hatching date of the first chick in a brood for JCOM, clutch initiation date for BTGL), clutch size, and the number of fledglings per active nest (nests with $\geq 1$ hatchling or egg)

\begin{tabular}{|c|c|c|c|}
\hline & Rhinoceros auklet (RHAU) & Japanese cormorants (JCOM) & Black-tailed gull (BTGL) \\
\hline No. of active nests & $190,000-290,000^{\mathrm{a}}$ & $500-1600^{\mathrm{a}}$ & $2500-30,000^{\mathrm{a}}$ \\
\hline Body mass $(\mathrm{kg})$ & $0.5-0.6^{\mathrm{b}}$ & $2.3-3.2^{\mathrm{e}}$ & $0.5-0.6^{\mathrm{h}}$ \\
\hline Foraging mode & Wing-propelled diving & Foot-propelled diving & Surface feeding \\
\hline Diving depth (m) & 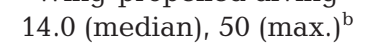 & $7.2-15.1$ (mean), 26-39 (max.) $)^{\mathrm{e}}$ & - \\
\hline Foraging range $(\mathrm{km})$ & $87(0.5-164)^{\mathrm{c}}$ & $10-22^{\mathrm{f}}$ & Around the island ${ }^{\mathrm{i}}$ \\
\hline Wintering area & Along Japan archipelago ${ }^{\mathrm{d}}$ & Along Japan archipelago ${ }^{g}$ & Along Japan archipelago ${ }^{\mathrm{j}}$ \\
\hline \multicolumn{4}{|c|}{ Percent chick diet in $1984-2009$ (median) ${ }^{1}$} \\
\hline Sardine & $0-24(0)$ & $0-19(0)$ & $0-53(0)$ \\
\hline Sandlance & $2-57(13)$ & $3-92(21)$ & $8-86(41)$ \\
\hline Anchovy & $1-95(69)$ & $0-49(13)$ & $0-65(20)$ \\
\hline Juvenile Japan Sea greenlir & $1-50(9)$ & $0(0)$ & $0(0)$ \\
\hline Greenlings & $0(0)$ & $0-60(22)$ & $0-34(0)$ \\
\hline Demersal fish & $0(0)$ & $3-69(16)$ & $0-12(0)$ \\
\hline Egg laying date ${ }^{1}$ & $1 \mathrm{Apr}-24 \mathrm{Apr}^{\mathrm{k}}$ & 8 Apr-27 Mayk & 5 May-28 May \\
\hline Hatch date & 16 May-9 Jun & 6 May-24 June & 2 Jun-25 Jun ${ }^{\mathrm{k}}$ \\
\hline Clutch size $^{1}$ & 1 & $2.6-4.0$ & $1.4-2.6$ \\
\hline No. of fledglings per nest ${ }^{1}$ & $0.3-0.9$ per nest with chick & $0.5-2.6$ per nest with egg & $0.0-1.2$ per nest with egg \\
\hline \multicolumn{4}{|c|}{ 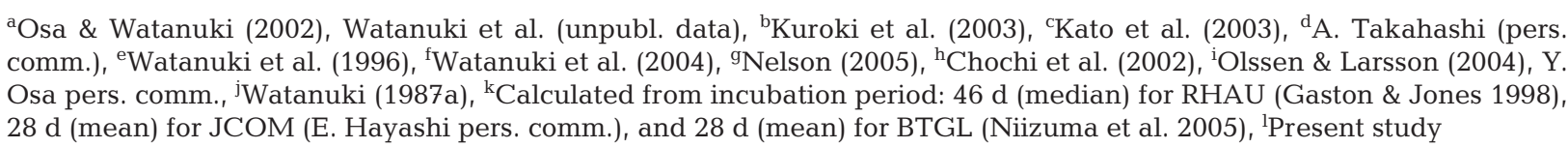 } \\
\hline
\end{tabular}

and thus disturbance of BTGL, we set 2 to 4 JCOM plots (ca. $20 \times 30 \mathrm{~m}$ ) on cliff faces by map and 2 to 4 BTGL plots (ca. $10 \times 10 \mathrm{~m}$ ) on slopes within stakes. Artificial nest boxes were set in part of the RHAU plot. Breeding success and chick growth did not differ between natural burrows and nest boxes (Kuroki et al. 1998).

For RHAU we walked in the plot and checked the presence of eggs or chicks in 10 to 66 nests annually, including nest boxes, every $5 \mathrm{~d}$. As RHAU are sensitive to disturbance during egg laying and incubation, we monitored them primarily after hatching. Chicks that disappeared from the nest after $40 \mathrm{~d}$ were considered to have fledged (Takahashi et al. 2001). We monitored the contents of 26 to 62 JCOM nests annually every $5 \mathrm{~d}$ from ca. $50 \mathrm{~m}$ away using a $20 \times$ to $40 \times$ telescope due to difficulties in approaching the nests. Chicks that disappeared after $45 \mathrm{~d}$ were considered to have fledged (Kato et al. 2001). For BTGL we walked in study plots and marked each nest with a numbered stake when we found newly laid eggs and banded newly hatched chicks. We monitored 30 to 104 nests annually and checked the presence of banded chicks every $5 \mathrm{~d}$. Chicks that disappeared after $30 \mathrm{~d}$ or after attaining $500 \mathrm{~g}$ were considered to have fledged (Watanuki 1987b).
As the indices of the timing of breeding in each year, we used the mean laying date of the first egg in BTGL nests, and the mean hatching date of RHAU (Fig. 2a). The mean hatching date of the first JCOM chick in nests was used as timing index for this species, as we did not identify egg laying by JCOM in some years. Development period of embryo, i.e. incubation period, is relatively constant in most homoeothermic bird species so both the timing of egg-laying and the timing of hatching can be used as an index for the timing of breeding. As an index of breeding success for RHAU, we used the number of fledglings produced per chick hatched per pair (Fig. 2b). For JCOM and BTGL, we used the number of fledglings produced per pair that had eggs.

\section{Collection and analysis of seabird diet}

RHAU bring back food cross-wise in their bills in the evening and night, and JCOM and BTGL, in the stomach during the day. We caught RHAU arriving with prey after sunset and collected 64 to 226 billloads each year. Chicks and adults of BTGL and JCOM sometimes vomited food when they were 
a) Timing of breeding

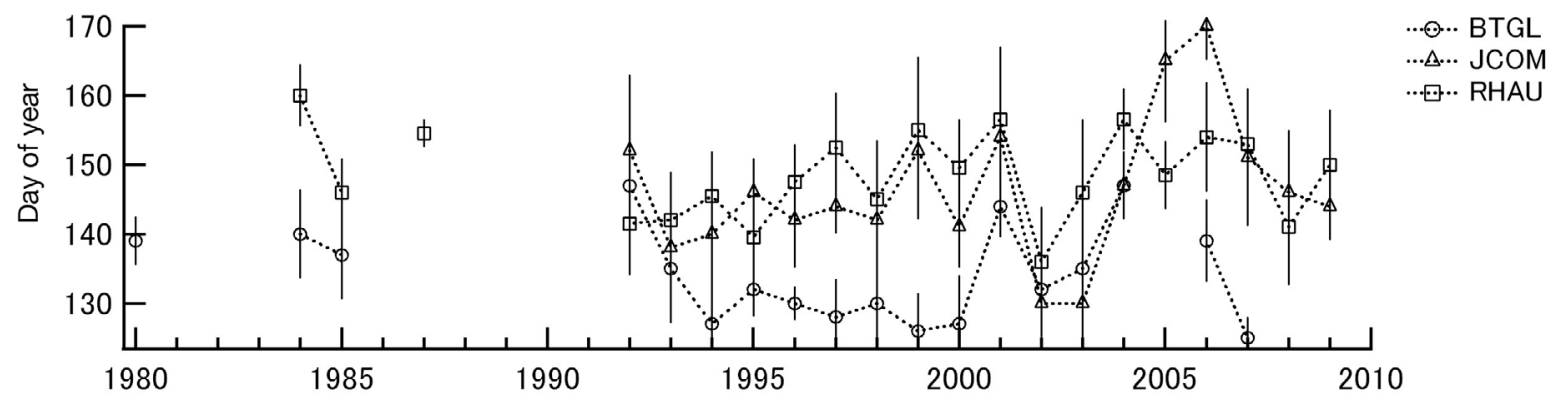

b) Breeding successs

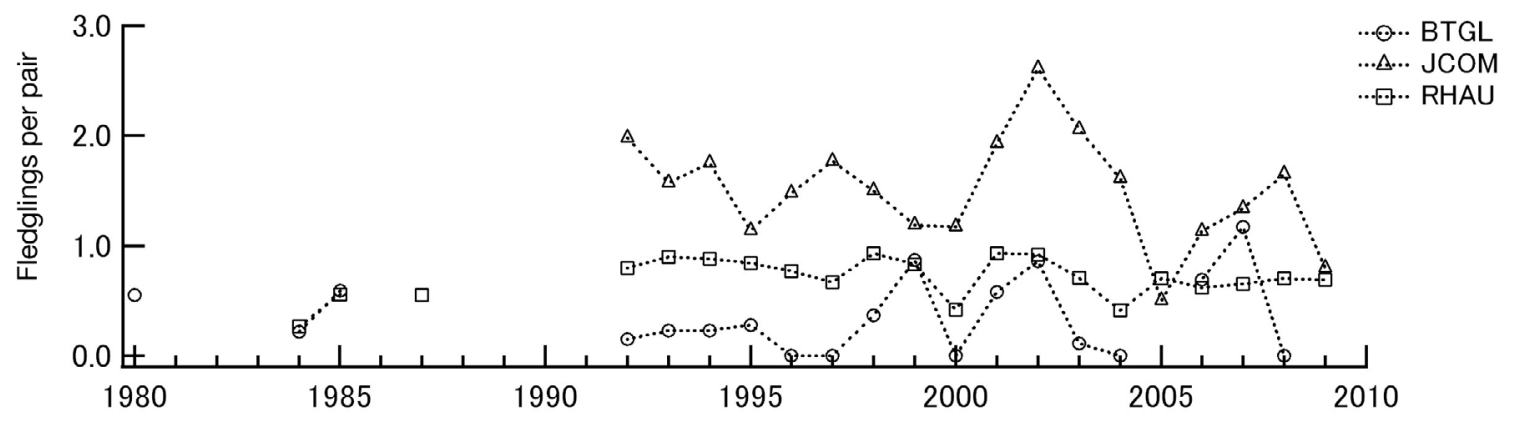

C) \% sardine or anchovy

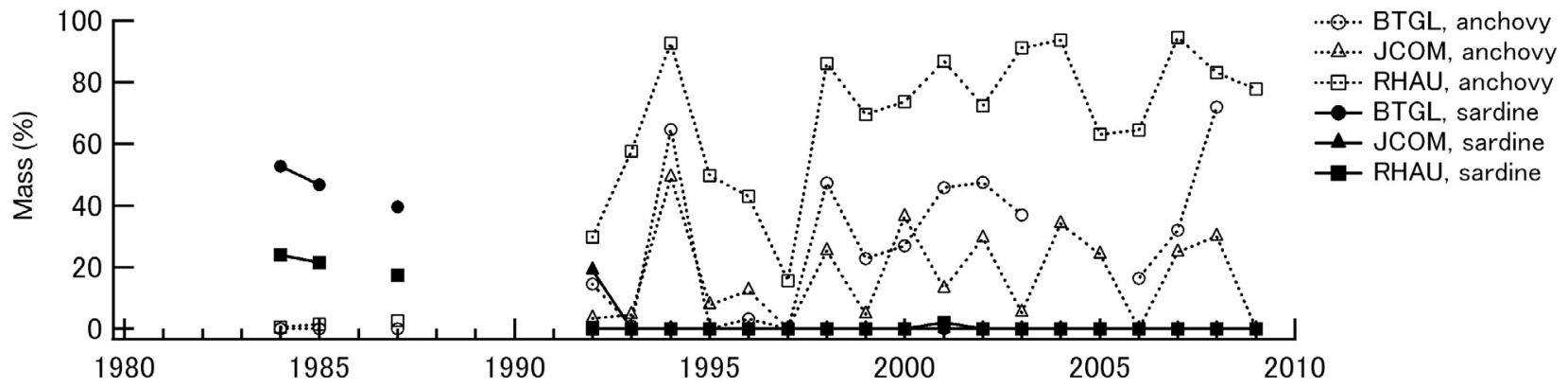

d) $\%$ sandlance in diet

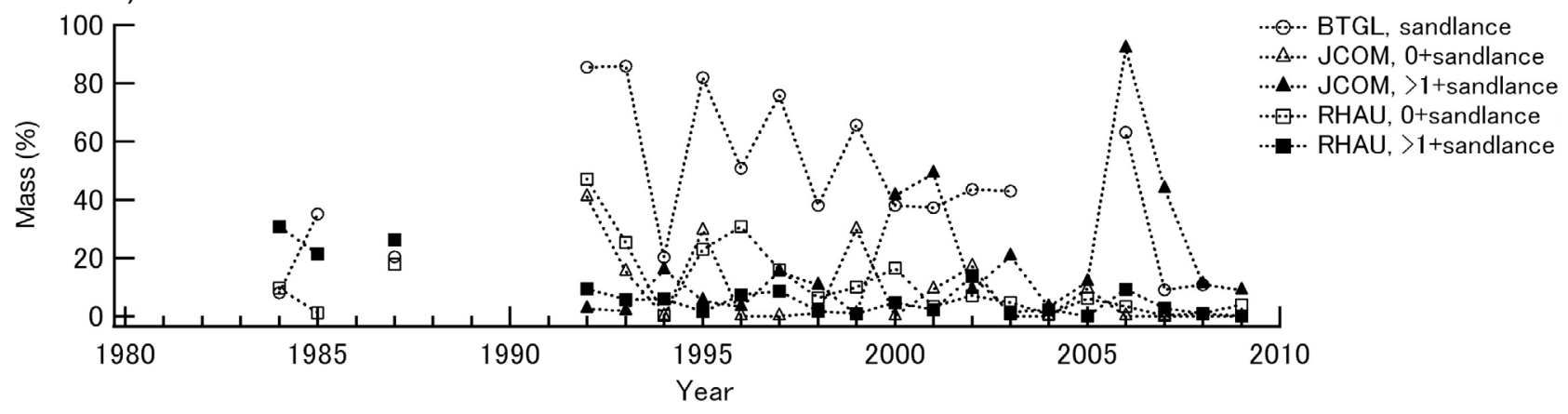

Fig. 2. Larus crassirostris, Cerorhinca monocerata, Phalacrocorax filamentosus. Interannual changes in (a) timing (mean $\pm 1 \mathrm{SD}$ ) of breeding, (b) breeding success, and (c,d) dietary composition of black-tailed gulls (BTGL), rhinoceros auklets (RHAU), and Japanese cormorants (JCOM). (a) The timing is represented by egg laying for BTGL and hatching for RHAU and JCOM. (b) Breeding success is shown as the mean number of fledglings per pair. (c) Changes in the mass proportion of sardine and anchovy in the diet. (d) Changes in the mass proportion of $0+$ sandlance and $>1+$ sandlance in the diet of RHAU and JCOM, and of all sandlance in the diet of BTGL 
caught, and we collected 19 to 115 regurgitations from BTGL and 21 to 37 from JCOM each year.

Each food sample was weighed, and prey items were sorted and weighed separately. Prey items were identified to the lowest possible taxonomic level. We estimated the length of prey fish from otolith size (Ishikawa \& Watanuki 2002) or we measured the total length of undigested fish. The sandlance were categorized into cohorts of $0+\mathrm{yr}$ $(<110 \mathrm{~mm}$ total length) and $>1+$ yr $(\geq 110 \mathrm{~mm})$ (Takahashi et al. 2001), although it was sometimes difficult in food samples of BTGL, since these were degraded. We also calculated the percentage mass of important prey (sardine, anchovy, $0+$ and $>1+$ sandlance) in the total each year (Fig. 2c,d).

\section{Prey abundance}

As indices of the availability of major prey in spring (krill, sandlance) and summer (anchovy, sandlance), we used the reported stock size of anchovy, catch per unit effort (CPUE) for krill, and the total annual catch of $0+$ sandlance from fisheries (Fig. 3a). Krill and 0+ sandlance are harvested in March to April and May, respectively, around the island. We used the CPUE for krill (KrillCPUE, annual catch per fishing days as reported by fishermen on Yagishiri Island, $\sim 4 \mathrm{~km}$ east of Teuri Island, in 1992 to 2007) and the annual catch of $0+$ sandlance around Teuri and Yagishiri Islands (CatSL0, published by the Department of Fisheries and Forestry from 1980 to 2005, and on www.pref.hokkaido.lg.jp from 2006). The Tsushima anchovy stock is distributed from the west coast of Kyushu to the Japan Sea coast, and is seasonally available for seabirds breeding on Teuri Island when its distribution extends to the north. Its stock size (ENGstock) has been estimated annually by the Fisheries Agency since 1991, and its trend has been validated by local acoustic surveys (http://abchan.job. affrc.go.jp, in Japanese).

\section{Local climate and broad-scale climate indices}

Wind, rain, snow, ice or low air temperatures can cause freezing of the Teuri nesting grounds, metabolic stress, and difficulty in finding food. Changes in ocean temperature (indexed by SST) may influence the distribution and abundance of prey. We used monthly (February to July) average air temperature (Temp.) and monthly rainfall (Rain) recorded on Yagishiri Island, and the total snowfall in March (Snow), when seabirds arrive at the colony, recorded at Haboro weather station ( $30 \mathrm{~km}$ east of Teuri Island) (www.data.jma.go.jp, in Japanese) to measure local weather conditions. We used monthly mean SST in an area of $60 \times 150 \mathrm{~km}$ around the island (Area A in Fig. 1, Fig. 3b) to index ocean temperature. Local SST in this sector was reported by Hakodate Kaiyou Kisyodai from 1985 (www.jma-net.go.jp/kahodate/menu/ sea.html, in Japanese); it was based on MGDSST (merged satellite and in situ data global daily SST) collected by the AVHRR (advanced very high resolution radiometer) sensor on NOAA (US National Oceanic and Atmospheric Administration) satellites and the Japanese multi-functional transport satellite (MTSAT).

Anchovy is harvested from waters with a SST of 12 to $15^{\circ} \mathrm{C}$ around Hokkaido (Mihara 1998), and seasonally expands its distribution northward during summer. RHAU switches prey from sandlance and juvenile greenling to anchovy when warm water $(\mathrm{SST}=$ $13^{\circ} \mathrm{C}$ ) arrives at the southern edge of its maximum foraging range (164 km; Table 1, Area C in Fig. 1) in late April to late June (Watanuki et al. 2009). We used the date of warm water arrival (WWA, www. jma-net.go.jp/kahodate/menu/sea.html, in Japanese) in the region as an index of the seasonal availability of anchovy to breeding seabirds.

We used an index of the flow rate of the TC (area of the water at $100 \mathrm{~m}$ depth with temperature $>10^{\circ} \mathrm{C}$ ) (www.data.kishou.go.jp/kaiyou/shindan/e_2/ maizuru_tsushima/maizuru_tsushima.html, in Japanese; Fig. 3c) to understand the effects of the flow on SST and the timing of the northern expansion of anchovy distribution. Surface chlorophyll a concentration $(\mathrm{chl} a)$ in spring was hypothesized to relate to the timing of breeding through the availability of local prey during the spring (krill and sandlance) and to the chick diets through availability of sandlance in summer. We used monthly (March to May) chl $a$ in an area of $81 \times 81 \mathrm{~km}$ around Teuri Island (Area B in Fig. 1, Fig. 3b) that was obtained from Ocean Color Web (http://oceancolor.gsfc.nasa.gov/) at a spatial resolution of $9 \mathrm{~km}$ by the SeaDAS 6.2 data analysis system reported after 1998 (http:// oceancolor.gsfc.nasa.gov/seadas/).

Broad-scale climate indices are known to influence local climate and then marine ecosystems in the North Pacific (Chiba \& Saino 2003, Minobe et al. 2004, Chiba et al. 2005). We used the Pacific Decadal Oscillation (PDO) index (www.data.kishou.go.jp/ shindan/b-1/pdo/pdo.html), which reflects changes in air pressure and SST over the Pacific; the North Pacific Index (NPI; www.data.kishou.go.jp/db/ 


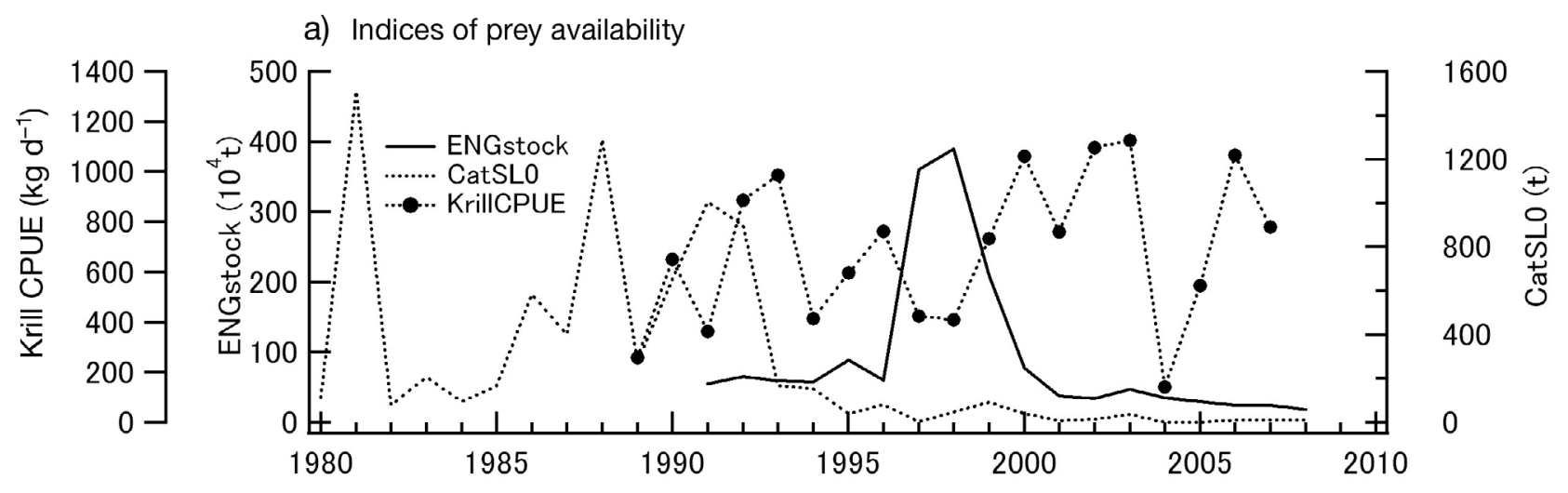

b) Local SST and Chl a

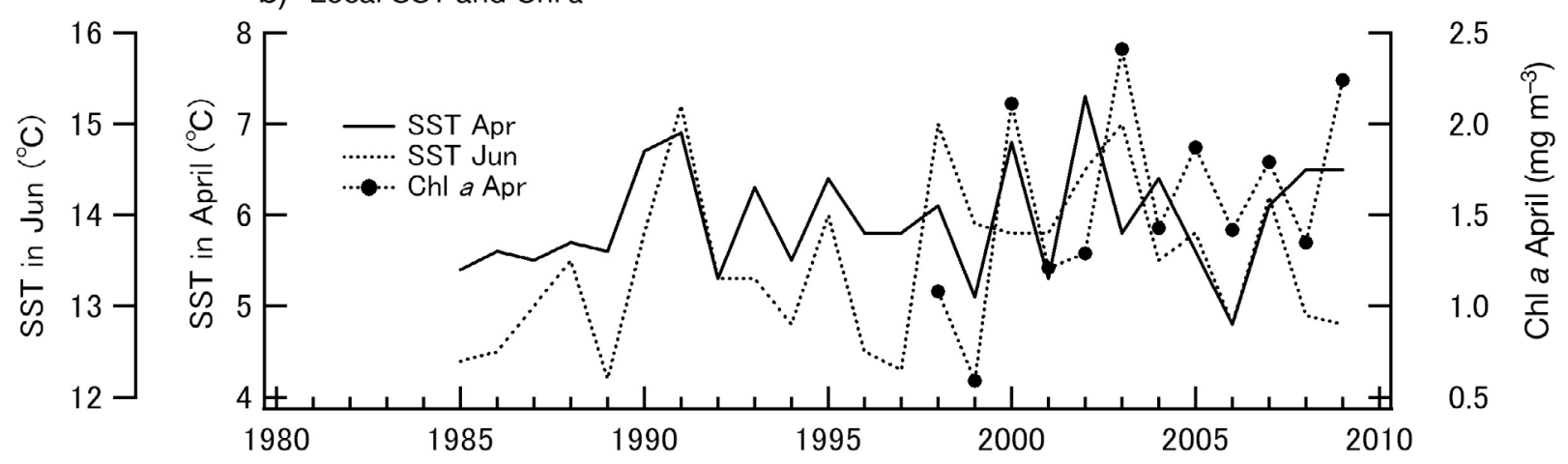

c) NE Japan Sea SST and Tsushima current

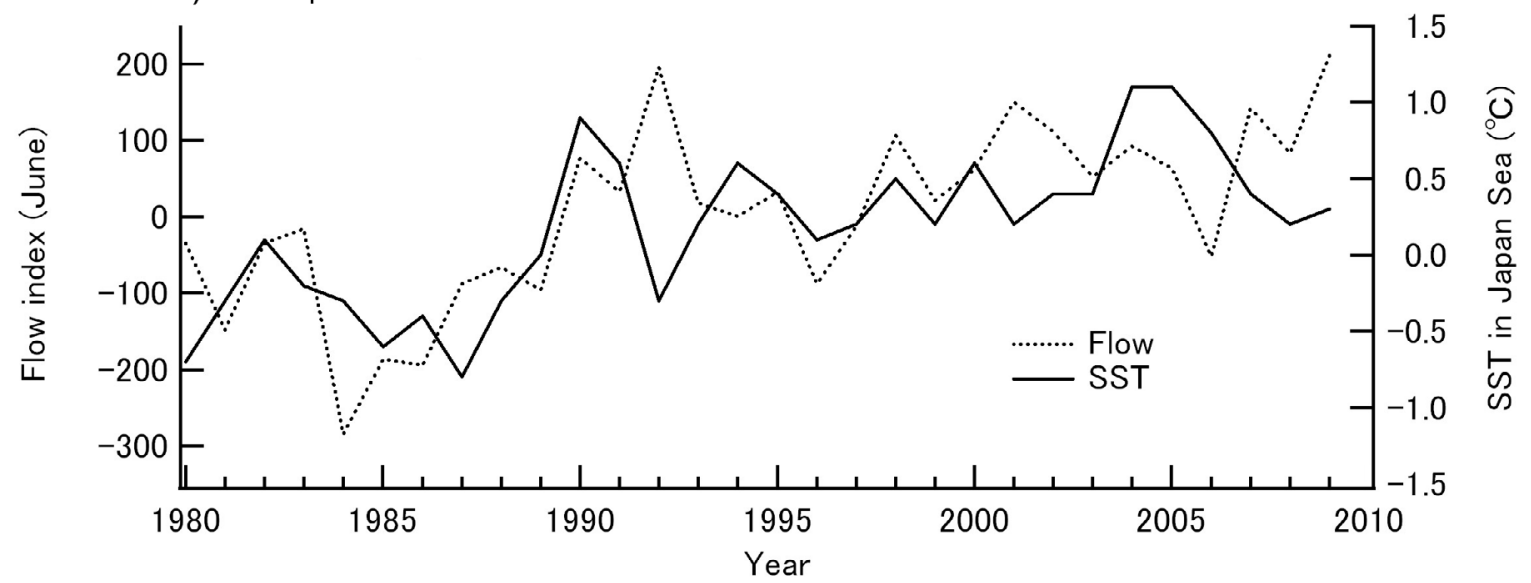

Fig. 3. (a) Estimated Tsushima anchovy Engraulis japonicus stock size (ENGstock), annual fishery harvest of 0+ sandlance Ammodytes personatus (CatSL0), and catch of krill Thysanoessa longipes and T. inermis per day (KrillCPUE) around Teuri Island. (b) Sea-surface temperature (SST) in Area A (Fig. 1) in April and June and surface chlorophyll a concentration in Area B (Fig. 1) in April. (c) Annual mean SST over the northeastern Japan Sea (www.data.jma.go.jp) and the Tsushima Current flow index in June

climate/pdo/npiwin.txt), which reflects the strength of the Aleutian low pressure; and the Arctic Oscillation (AO) index (www.cpc.ncep.noaa.gov.products/ precip/CWlink/daily_ao_index), which reflects the difference in air pressure between the Arctic and mid-latitudinal area of the North Pacific.

\section{Analyses}

To test for long-term interannual trends in seabird diet and breeding, we used simple linear regression analyses. To identify effects of local climatic factors and prey availability indices on variation in the tim- 
ing of breeding, diet, and breeding success (the dependent variables), we used path analysis with Amos V. 6.0 software (Amos Development Corporation). For Temp., Rain, and SST in February to June, we used those in the month in which each had the strongest correlation (largest Pearson's r) with the dependent variables. In addition, we used annual values of Snow in March, CatSL0, KrillCPUE, and WWA. To simplify the analysis, indirect effects such as those of the TC flow on SST were not included in the models but examined separately. If correlation between potential independent variables was significant, co-variance between these was included in the potential path models. Year was included as a potential independent factor to test for trends in seabird diet and breeding performance. The model giving the smallest value of the Akaike Information Criterion (AIC) was selected as the best fitting model, and the top 3 models $(\triangle \mathrm{AIC}<2.0)$ were considered as potential models (Burnham \& Anderson 1998). Following Frederiksen et al. (2004), we examined whether the slopes of factors were significant using Type III sums of squares, and used the $\mathrm{R}^{2}$ value (coefficient of determination) as the proportion of variance explained by each model.

The TC flow can indirectly affect the breeding biology and diets of seabirds through changes in SST and WWA (Watanuki et al. 2009). To look at the effects of the flow index on SST and WWA, we performed linear regression analyses using 1985 to 2009 data. To understand how broad-scale climate relates to the local climate factors, we performed path analyses using long-term data (1943 to 2008) in which PDO, NPI, and winter average AO were independent and Temp. in April, Snow, mean February wind speed recorded at Yagishiri Island, and the TC flow index in June were dependent variables.

Chl a data were collected from 1998. Because of the small sample size $(12 \mathrm{yr})$, we used simple linear regression analyses to examine the effects of chl $a$ on the availability of krill and sandlance that were harvested around the island and the proportion of these species in the diet.

\section{RESULTS}

\section{Trends in climate and seabird parameters}

We found no significant 1 yr lagged autocorrelations in the timing of breeding or breeding success of any species $(p>0.05)$. No significant inter-annual linear trends were found in the timing of breeding or the breeding success in all 3 seabird species, or in the mass proportion of $0+$ sandlance, $>1+$ sandlance, and sandlance in the diet of RHAU, JCOM, and BTGL, respectively ( $p>0.05$; Fig. 2 ). There were increasing trends in the mass proportion of anchovy in the diet of RHAU $(\mathrm{r}=0.788, \mathrm{n}=21, \mathrm{p}<0.01)$ and BTGL $(\mathrm{r}=$ $0.614, \mathrm{n}=18, \mathrm{p}<0.01$ ), though that for JCOM showed no trend ( $p>0.05)$, presumably because no JCOM diet data were available before 1991 (Fig. 2c). Negative trends were found in the mass proportion of $0+$ sandlance in the diet of JCOM $(r=-0.510, \mathrm{n}=18$, $\mathrm{p}<0.05$ ) and that of $>1+$ sandlance in the diet of RHAU ( $r=0.767, \mathrm{n}=21, \mathrm{p}<0.001$; Fig. 2d).

During the study period, there were increasing linear trends in Temp. $(\mathrm{r}=0.448$ to $0.539, \mathrm{n}=21, \mathrm{p}<$ $0.05)$, except in June $(p>0.05)$ and in the TC flow index $(\mathrm{r}=0.477$ to $0.658, \mathrm{n}=20, \mathrm{p}<0.05)$. No trends were observed in Rain ( $\mathrm{p}>0.05)$, except in May $(\mathrm{r}=$ $0.546, \mathrm{n}=21, \mathrm{p}=0.009)$, Snow, SST and WWA ( $\mathrm{p}>$ 0.05). ENGstock and KrillCPUE showed no significant trends $(p>0.05)$, but CatSL0 showed a decreasing trend $(r=0.492, n=19, p=0.03)$.

\section{Timing of breeding}

RHAU bred later in years with cold Temp. in April (Fig. 4), heavy Snow, and little Rain in April in the top 3 models, though $\triangle$ AIC were small among models (Table 2). JCOM bred later in years with cold air temperature and lower SST in April in the top 3 models, though as was seen for RHAU, $\triangle$ AIC were small among models (Fig. 4, Table 2). For the laying date of BTGL, $\triangle$ AIC were too small among top models to pick consistently significant factors (Table 2). Chl a peaked in April in 10 out of $12 \mathrm{yr}$ and in May in the other years. Simple linear regression analyses indicate that Chl a in March to May did not relate to the timing of breeding for any species $(p>0.05)$.

\section{Chick diet}

In the 2 top models, RHAU fed more on anchovy in years when WWA was earlier, though $\triangle$ AIC were small among models (Table 3). However, surprisingly ENGstock was not included in the top 3 models (Table 3). JCOM fed more on 0+ sandlance in years with high CatSL0 in 3 top models (Table 3). The null model was selected as top model, and no factors explained the proportion of sandlance in the diet of BTGL (Table 3). Chl $a$ in March to May did not relate to the spring prey availability indices (KrillCPUE: 


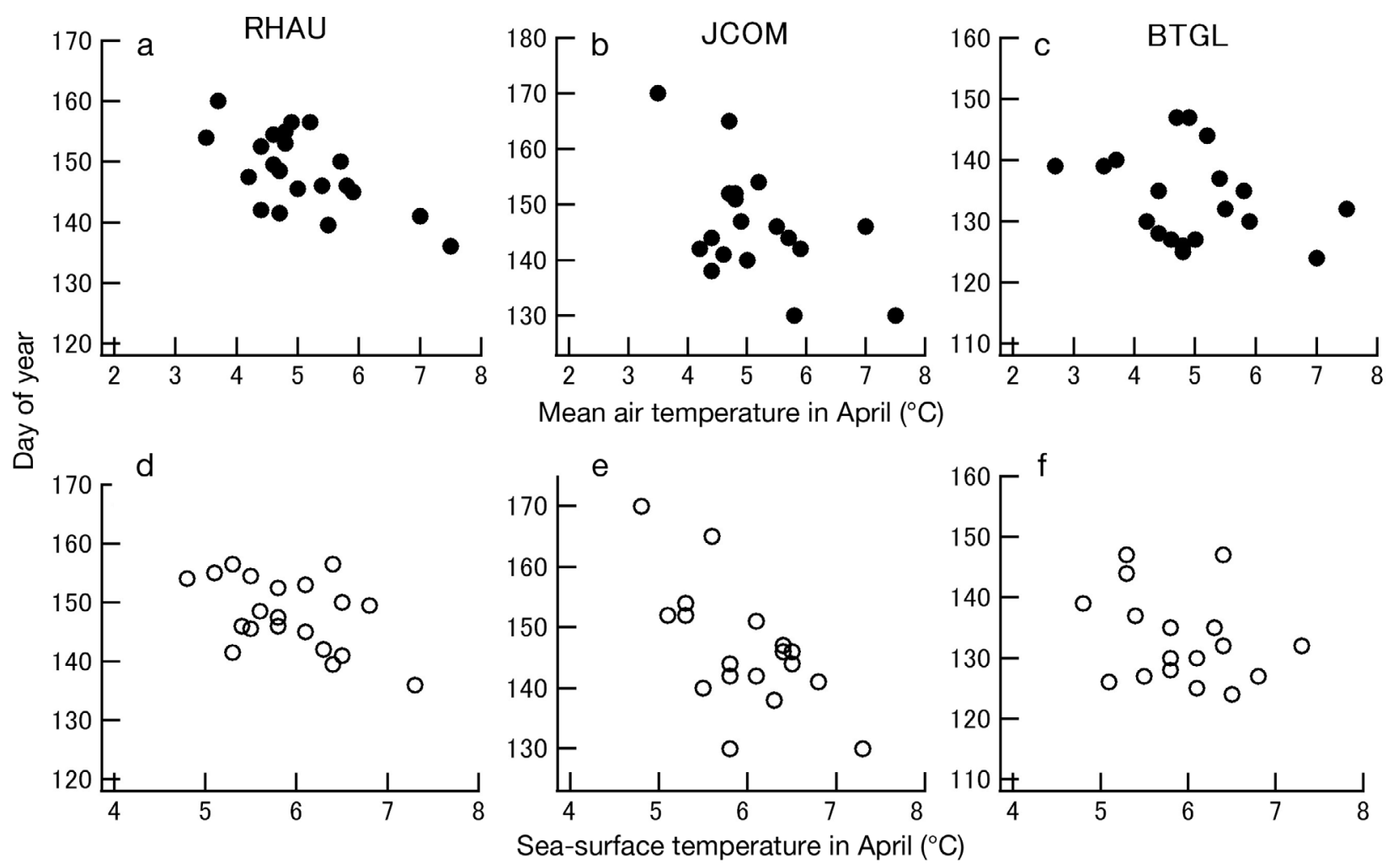

Fig. 4. Cerorhinca monocerata, Phalacrocorax filamentosus, Larus crassirostris. Relationships between the mean air temperature (Temp.) in April $(\mathrm{a}, \mathrm{b}, \mathrm{c} ; \mathbf{O})$ or sea-surface temperature (SST) around the colony in April (d, e, $\left.\mathrm{f}_{;} \mathrm{O}\right)$, the mean egg laying date of black-tailed gulls (BTGL) and the mean hatching dates of rhinoceros auklets (RHAU) and Japanese cormorants (JCOM)

Table 2. Cerorhinca monocerata, Phalacrocorax filamentosus, Larus crassirostris. Fitted path models relating timing of breeding (laying date for black-tailed gulls [BTGL]; hatching date for rhinoceros auklet [RHAU] and Japanese cormorant [JCOM]) to monthly mean air temperature (Temp.) in April, total snowfall (Snow) in March, total rainfall (Rain) in April, local seasurface temperature (SST) in April, and krill capture per unit effort (CPUE). Year is also included as a factor. Covariance between Temp. in April and SST in April was significant $(\mathrm{r}=0.446, \mathrm{p}<0.05)$ and included in all models. Models having $\Delta$ AIC $<$ 2.0 but up to the third-best models are shown. $\triangle \mathrm{AIC}$, parameter estimates (with $\mathrm{SE}$ and significance in parentheses), and the coefficient of determination $\left(\mathrm{R}^{2}\right)$ are also shown. - = independent variable not selected

\begin{tabular}{|c|c|c|c|c|c|c|c|c|}
\hline Species & $\Delta \mathrm{AIC}$ & Year & Temp. (Apr) & Snow (Mar) & Rain (Apr) & SST (Apr) & Krill CPUE & $\mathrm{R}^{2}$ \\
\hline \multirow[t]{3}{*}{$\begin{array}{l}\text { RHAU } \\
\text { (hatching) }\end{array}$} & 0.000 & - & $\begin{array}{c}-3.115 \\
(0.895,<0.001)\end{array}$ & $\begin{array}{c}0.063 \\
(0.024,0.008)\end{array}$ & $\begin{array}{c}-0.119 \\
(0.049,0.014)\end{array}$ & - & - & 0.584 \\
\hline & 0.529 & - & $\begin{array}{c}-2.216 \\
(1.122,0.048)\end{array}$ & $\begin{array}{c}0.068 \\
(0.023,0.003)\end{array}$ & $\begin{array}{c}-0.112 \\
(0.047,0.017)\end{array}$ & $\begin{array}{c}-2.217 \\
(1.712,0.195)\end{array}$ & - & 0.598 \\
\hline & 1.654 & - & $\begin{array}{c}-3.179 \\
(0.887,<0.001)\end{array}$ & $\begin{array}{c}0.064 \\
(0.024,0.007)\end{array}$ & $\begin{array}{c}-0.103 \\
(0.048,0.032)\end{array}$ & - & $\begin{array}{c}-0.002 \\
(0.003,0.491)\end{array}$ & 0.560 \\
\hline \multirow[t]{3}{*}{$\begin{array}{l}\text { JCOM } \\
\text { (hatching) }\end{array}$} & 0.000 & $\begin{array}{c}1.007 \\
(0.259,<0.001)\end{array}$ & $\begin{array}{c}-4.556 \\
(1.815,0.012)\end{array}$ & $\begin{array}{c}-0.057 \\
(0.036,0.108)\end{array}$ & - & $\begin{array}{c}-7.595 \\
(2.793,0.007)\end{array}$ & - & 0.759 \\
\hline & 0.122 & $\begin{array}{c}0.883 \\
(0.276,0.001)\end{array}$ & $\begin{array}{c}-3.789 \\
(1.930,0.050)\end{array}$ & - & - & $\begin{array}{c}-8.137 \\
(2.971,0.006)\end{array}$ & - & 0.699 \\
\hline & 1.066 & $\begin{array}{c}1.026 \\
(0.253,<0.001)\end{array}$ & $\begin{array}{c}-4.531 \\
(1.770,0.010)\end{array}$ & $\begin{array}{c}-0.059 \\
(0.035,0.092)\end{array}$ & - & $\begin{array}{c}-7.555 \\
(2.725,0.006)\end{array}$ & $\begin{array}{c}-0.005 \\
(0.005,0.347)\end{array}$ & 0.773 \\
\hline \multirow[t]{3}{*}{$\begin{array}{l}\text { BTGL } \\
\text { (laying) }\end{array}$} & 0.000 & - & - & - & - & $\begin{array}{c}-0.732 \\
(0.498,0.141)\end{array}$ & - & 0.112 \\
\hline & 0.085 & - & - & - & $\begin{array}{c}0.026 \\
(0.018,0.137)\end{array}$ & $\begin{array}{c}-0.987 \\
(0.469,0.035)\end{array}$ & - & 0.276 \\
\hline & 0.276 & - & - & - & - & - & - & 0.000 \\
\hline
\end{tabular}


$\mathrm{p}>0.05$; CatSL0: $\mathrm{p}>0.05)$. Chl $a$ in these months did not relate to the proportion of $0+$ or $>1+$ sandlance in the diet of RHAU and BTGL ( $p>0.05$ ) either. There was significant negative correlation between $\mathrm{Chl} a$ in April and the proportion of $0+$ sandlance in the diet of $\operatorname{JCOM}(r=-0.629, n=12, p=0.03)$, though its biological significance was unclear.

\section{Breeding success}

For RHAU, the top 3 models showed that breeding success was greater in years with earlier onset of breeding and earlier WWA (Table 4). For JCOM, the top 3 models showed that breeding success was greater in years with earlier breeding, lower Temp. and less Rain in June, earlier WWA, and greater CatSL0 (Table 4). The breeding success in BTGL varied widely between years and appeared to be greater in years with earlier WWA.

\section{Interactions of local and large-scale climate}

The TC flow index in May and June was negatively related to WWA ( $\mathrm{r}=-0.588$ to $-0.495, \mathrm{n}=17$, $\mathrm{p}=0.03$ to 0.01 ), indicating that warm waters arrived later when the flow rate was reduced. June SST increased when the June TC flow was stronger $(\mathrm{r}=0.493, \mathrm{n}=17, \mathrm{p}=0.027)$. Temp. in April was positively associated with the winter AO index in the top 3 models (Table 5). The mean wind speed in February was negatively associated with the winter AO index and positively associated with the NPI in the top 3 models (Table 5). Snow in March was negatively associated with winter $\mathrm{AO}$ and increased interannually in the top 2 models. The TC flow index in June was negatively associated with the PDO index and increased interannually (see Fig. 3c also) in the top 3 models. This indicates that anomalously low SST on the western side of the Pacific related to a weak TC in June.

Table 3. Cerorhinca monocerata, Phalacrocorax filamentosus, Larus crassirostris. Fitted path models relating the mass proportion of anchovy (for rhinoceros auklet [RHAU] and Japanese cormorant [JCOM]), 0+ and >1+sandlance (for JCOM) or sandlance (for black-tailed gulls [BTGL]) in bird's diet to local sea-surface temperature (SST) in June, the date of arrival of $13^{\circ} \mathrm{C}$ water within the RHAU foraging range (WWA), the stock size of anchovy (ENGstock), and the annual catch of 0+ sandlance (CatSL0). Year is also included as a factor. Covariance between WWA and SST in June was significant $(r=-0.664, p<0.05)$ and was included in all models. Models having $\triangle \mathrm{AIC}<2.0$ but up to the third-best models are shown. $\Delta$ AIC, parameter estimates (with SE and significance in parentheses), and the coefficient of determination $\left(\mathrm{R}^{2}\right)$ are shown. $-=$ independent variable not selected

\begin{tabular}{|c|c|c|c|c|c|c|c|}
\hline Species & $\Delta \mathrm{AIC}$ & Year & SST (Jun) & WWA & ENGstock & CatSL0 & $\mathrm{R}^{2}$ \\
\hline \multirow[t]{3}{*}{$\begin{array}{l}\text { RHAU } \\
\text { (anchovy) }\end{array}$} & 0.000 & $\begin{array}{c}3.258 \\
(0.506,0.001)\end{array}$ & - & $\begin{array}{c}-1.787 \\
(0.609,0.003)\end{array}$ & - & - & 0.722 \\
\hline & 1.087 & $\begin{array}{c}2.988 \\
(0.495,0.001)\end{array}$ & - & $\begin{array}{c}-1.874 \\
(0.593,0.002)\end{array}$ & - & - & 0.714 \\
\hline & 1.203 & $\begin{array}{c}3.023 \\
(0.519,0.001)\end{array}$ & $\begin{array}{c}13.181 \\
(4.765,0.006)\end{array}$ & - & - & $\begin{array}{c}-0.019 \\
(0.018,0.282)\end{array}$ & 0.679 \\
\hline \multirow[t]{3}{*}{$\begin{array}{l}\text { JCOM } \\
(0+\text { sandlance })\end{array}$} & 0.000 & - & - & - & - & $\begin{array}{c}0.039 \\
(0.011,<0.001)\end{array}$ & 0.415 \\
\hline & 0.366 & - & $\begin{array}{c}3.789 \\
(2.884,0.189)\end{array}$ & - & - & $\begin{array}{c}0.041 \\
(0.011,<0.001)\end{array}$ & 0.484 \\
\hline & 0.389 & - & - & $\begin{array}{c}-0.481 \\
(0.370,0.194)\end{array}$ & - & $\begin{array}{c}0.037 \\
(0.011,<0.001)\end{array}$ & 0.442 \\
\hline \multirow[t]{3}{*}{$\begin{array}{l}\text { JCOM } \\
(>1+\text { sandlance })\end{array}$} & 0.000 & $\begin{array}{c}1.688 \\
(0.979,0.085)\end{array}$ & - & - & - & - & 0.148 \\
\hline & 0.743 & - & - & - & - & - & 0.000 \\
\hline & 1.644 & - & - & - & - & $\begin{array}{c}-0.028 \\
(0.026,0.289)\end{array}$ & 0.065 \\
\hline JCOM & 0.000 & - & - & - & - & - & 0.000 \\
\hline (anchovy) & 0.918 & - & - & $\begin{array}{c}-0.585 \\
(0.559,0.296)\end{array}$ & - & - & 0.062 \\
\hline \multirow{3}{*}{$\begin{array}{l}\text { BTGL } \\
\text { (sandlance) }\end{array}$} & 0.000 & - & - & - & - & - & 0.000 \\
\hline & 0.631 & - & - & - & - & $\begin{array}{c}0.034 \\
(0.029,0.249)\end{array}$ & 0.072 \\
\hline & 1.053 & - & - & - & $\begin{array}{c}0.057 \\
(0.058,0.330)\end{array}$ & - & 0.061 \\
\hline
\end{tabular}




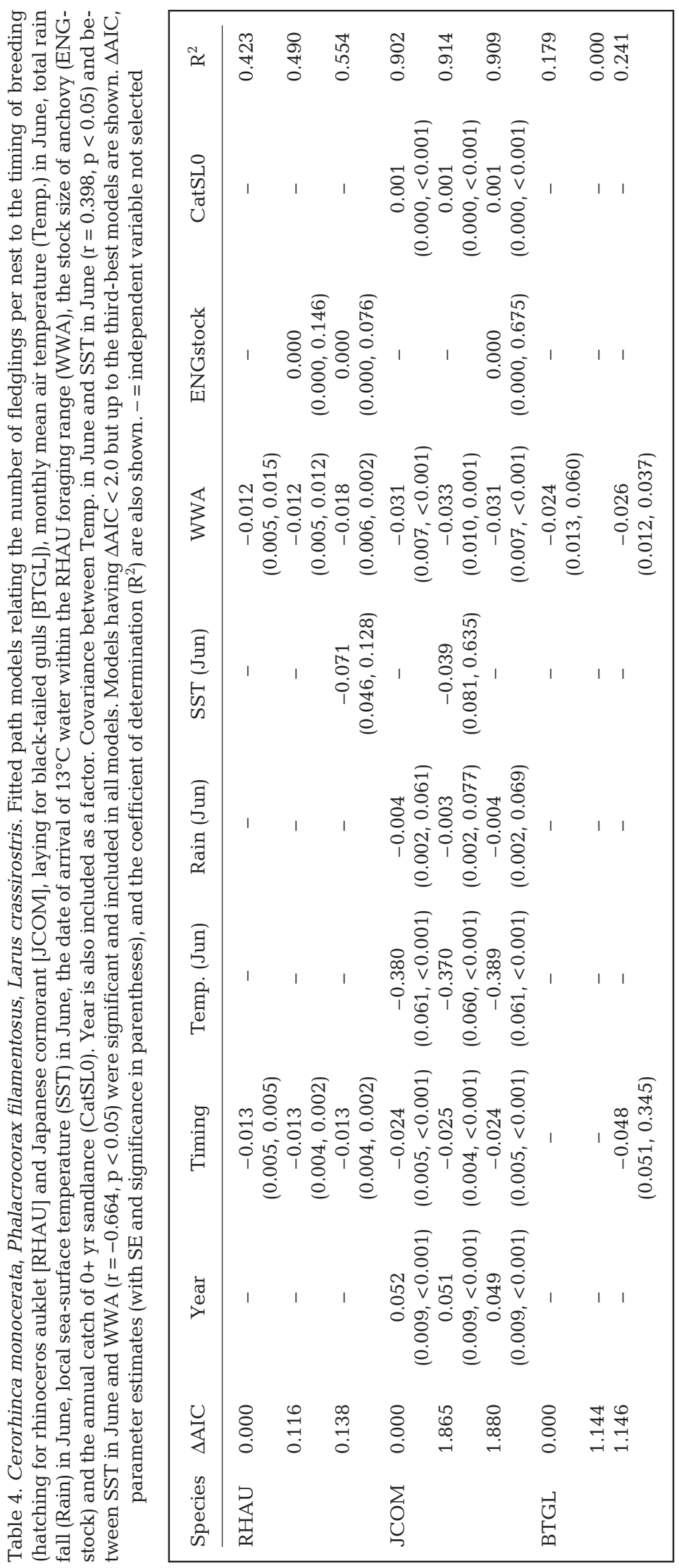

\section{DISCUSSION}

We conducted an analysis of seabird-climate relationships for the northern Japan Sea, thereby updating previous long-term studies of this region, prey and seabirds (Takahashi et al. 2001, Deguchi et al. 2004, Ito et al. 2009, Watanuki et al. 2009). In the present paper, we focused on examining trends in climatic factors and seabird parameters as our time series is now of sufficient duration to investigate directional climate change as well as climate variability. The present study is significant, as relatively few long-term seabird studies have been carried out in the western North Pacific (Kitaysky \& Golubova 2000, Watanuki et al. 2009). Our approach was to test for trends in large-scale and local climate indices and seabird parameters, and to relate factors using regression and AIC model selection procedures. We first tested the seabird parameters and found no evidence of autocorrelation.

\section{Timing of breeding}

Climate factors affected the timing of breeding, but differently between species. RHAU bred earlier in years with a warm and wet spring and little snow, probably because frozen soil and snow prevent them from excavating their burrows (Watanuki 1987a, Watanuki et al. 2009). JCOM bred earlier in years with higher spring SST and air temperature. Catches of adult Japan Sea greenlings in the study region tended to be higher in years with a warmer winter (Hoshino et al. 2009), and flatfish come to shore during early spring and spawn earlier in warmer regions (Nagasawa \& Torisawa 1991, Minami 1995). Thus, the abundance and seasonality of these prey species of JCOM in spring (M. Ito unpubl. data) might be related to the timing of JCOM. BTGL laid eggs earlier in years when the spring SST was from 3.0 to $4.9^{\circ} \mathrm{C}$ (Tomita et al. 2009), since swarms of krill, i.e. the main prey of BTGL in spring, occur at the surface with this range of SSTs in this region (Hanamura et al. 1989). However, we could not find any consistent linear effects of spring SST and krill CPUE on BTGL timing (Fig. 4, Table 2), so that longer term studies including other climate factors and more appropriate prey availability measures should be carried out before conclusions can be drawn. 
Table 5. Fitted path models relating local physical factors (air temperature in April at Yagishiri, Temp. [Apr]; average wind speed at Yagishiri in February, Wind [Feb]; total snowfall in March at Haboro, Snow [Mar]; Tsushima current flow index in June, Flow [Jun]; to Pacific Decadal Oscillation [PDO], North Pacific Index [NPI] and average winter Arctic Oscillation [AOav; December to February]) index. Year is also included as a factor. Covariance between Year and PDO $(r=0.310, p<0.05)$, between year and AO (winter) $(\mathrm{r}=0.345, \mathrm{p}<0.001)$, and between PDO and NPI $(\mathrm{r}=-0.531, \mathrm{p}<0.01)$ were significant and included in all models. Models having $\triangle \mathrm{AIC}<2.0$ but up to the third-best models are shown. $\triangle \mathrm{AIC}$, parameter estimates (with SE and significance in parentheses), and the coefficient of determination $\left(\mathrm{R}^{2}\right)$ are shown. $-=$ independent variable not selected

\begin{tabular}{|c|c|c|c|c|c|c|}
\hline & $\Delta \mathrm{AIC}$ & Year & PDO & NPI & AOav & $\mathrm{R}^{2}$ \\
\hline \multirow[t]{3}{*}{ Temp. (Apr) } & 0.000 & - & - & - & $\begin{array}{c}1.071 \\
(0.335,0.001)\end{array}$ & 0.142 \\
\hline & 0.924 & $\begin{array}{c}0.008 \\
(0.007,0.285)\end{array}$ & - & - & $\begin{array}{c}0.901 \\
(0.368,0.014)\end{array}$ & 0.148 \\
\hline & 1.201 & - & - & $\begin{array}{c}0.144 \\
(0.161,0.370)\end{array}$ & $\begin{array}{c}1.014 \\
(0.334,0.002)\end{array}$ & 0.142 \\
\hline \multirow[t]{3}{*}{ Wind (Feb) } & 0.000 & - & - & $\begin{array}{c}0.312 \\
(0.130,0.017)\end{array}$ & $\begin{array}{c}-0.687 \\
(0.288,0.017)\end{array}$ & 0.170 \\
\hline & 1.639 & - & $\begin{array}{c}-0.066 \\
(0.154,0.668)\end{array}$ & $\begin{array}{c}0.269 \\
(0.154,0.080)\end{array}$ & $\begin{array}{c}-0.680 \\
(0.288,0.018)\end{array}$ & 0.165 \\
\hline & 1.974 & $\begin{array}{c}0.001 \\
(0.006,0.849)\end{array}$ & - & $\begin{array}{c}0.319 \\
(0.308,0.014)\end{array}$ & $\begin{array}{c}-0.708 \\
(0.308,0.022)\end{array}$ & 0.174 \\
\hline \multirow[t]{2}{*}{ Snow (Mar) } & 0.000 & $\begin{array}{c}0.478 \\
(0.211,0.023)\end{array}$ & - & - & $\begin{array}{c}-24.739 \\
(10.329,0.017)\end{array}$ & 0.124 \\
\hline & 1.071 & $\begin{array}{c}0.543 \\
(0.218,0.013)\end{array}$ & $\begin{array}{c}-4.372 \\
(4.521,0.334)\end{array}$ & - & $\begin{array}{c}-26.775 \\
(10.295,0.009)\end{array}$ & 0.144 \\
\hline \multirow[t]{3}{*}{ Flow (Jun) } & 0.000 & $\begin{array}{c}4.383 \\
(0.664,<0.001)\end{array}$ & $\begin{array}{c}-55.414 \\
(14.794,<0.001)\end{array}$ & - & - & 0.499 \\
\hline & 0.535 & $\begin{array}{c}4.078 \\
(0.708,<0.001)\end{array}$ & $\begin{array}{c}-52.700 \\
(14.654,<0.001)\end{array}$ & - & $\begin{array}{c}40.033 \\
(33.173,0.228)\end{array}$ & 0.515 \\
\hline & 1.271 & $\begin{array}{c}4.296 \\
(0.666,<0.001)\end{array}$ & $\begin{array}{c}-46.814 \\
(16.878,<0.001)\end{array}$ & $\begin{array}{c}14.138 \\
(15.849,0.372)\end{array}$ & - & 0.505 \\
\hline
\end{tabular}

Using path analyses the effect of year on the timing of JCOM was significant (Table 2) presumably because JCOM timing was extraordinary late in 2005 and 2006 (Fig. 2a). Thus, at least between 1992 and 2009, there did not appear to be long-term linear trends in the timing of breeding in seabirds in our region. During the past 30 to $50 \mathrm{yr}$, the timing of seabird breeding has advanced in the Arctic (Gaston et al. 2009, Moe et al. 2009), but has been delayed in the Antarctic (Barbraud \& Weimerskirch 2006). In the temperate zone, results are more variable; laying or hatching occurs later in the western North Sea (Frederiksen et al. 2004, Wanless et al. 2008), where the North Atlantic Oscillation index has been decreasing, but earlier in the Canadian Pacific (Bertram et al. 2001, but see Hipfner at www.dfo-mpo.gc.ca/CSAS/ Csas/publications/resdocs-docrech/2010/2010_053_e. pdf), where SST has been increasing. No apparent trends were observed for auklets off the California coast (Thayer \& Sydeman 2007, Schroeder et al. 2009), but murres have been observed earlier (W. Sydeman pers. comm.). No change has been observed for Southeast Alaska (Slater \& Byrd 2009). Thus, the impact of global warming on the timing of seabird breeding appears to be variable among regions, presumably depending on the local ecosystem and climate system. There could also be agedependent differences (Pinaud \& Weimerskirch 2002) in seabird responses to climate variability and change. We cannot evaluate this hypothesis for our unmarked populations in the Japan Sea, but the variability observed in global patterns of seabird timing in relation to climate certainly may be related to agespecific breeding phenology and the age structure of studied seabird populations.

\section{Chick diet}

Decadal and interannual variability of local climate factors and prey availability affected the seabird diet. RHAU and BTGL fed on sardine and sandlance from 1984 to 1987, but RHAU fed on anchovy and BTGL on sandlance after 1992 (see also Deguchi et al. 2004). These decadal changes in chick diet reflected the cold-to-warm regime shift in the late 1980s in the TC region (see also Fig. 3c), with a steep decrease in the catch of cold-water sardine and an increase in the 
catch of warm-water anchovy (Tian et al. 2008). Anchovy spawn in the western North Pacific at a SST of 15 to $28^{\circ} \mathrm{C}$, and sardine, at 13 to $20^{\circ} \mathrm{C}$ (Takasuka et al. 2008). Cumulative mortality through the early life stages of sardine between 1988 and 1991, when SST was higher, apparently caused the stock to crash (Watanabe et al. 1995).

Interannual variation in the proportion of anchovy in the diet of RHAU was explained by the timing of the arrival of warm water $\left(\mathrm{SST}=13^{\circ} \mathrm{C}\right)$ within the bird's foraging range. In years with a strong $\mathrm{TC}$, RHAU switched prey earlier from cold-water species (sandlance and juvenile greenlings; Nagasawa \& Torisawa 1991) to anchovy and hence fed more on anchovy in these years (Watanuki et al. 2009). The annual catch of $0+$ sandlance was positively related to the proportion of $0+$ sandlance in the diet of JCOM, supporting the relationship between the seabird diet and local prey availability. The proportion of sandlance in the diet of BTGL, however, could not be explained by either local climate factors or the catch of $0+$ sandlance. This is surprising as BTGL are surface feeders and feed mainly on sandlance (Deguchi et al. 2004; Table 1, Fig. 2d). Possibly because of a narrow foraging habitat, BTGL might not be able to switch to anchovy when they become available.

\section{Breeding success}

There were no trends in the breeding success of seabirds on Teuri Island. Breeding success of RHAU was determined by the arrival of warm water in the northern Japan Sea. Increasing breeding success was correlated with earlier arrival dates of the warm TC because anchovy were advected into this region with the warm waters and provided more energy to chicks than other prey (Watanuki et al. 2009). Yet, we found no evidence that breeding success was significantly influenced by the anchovy stock size (Table 4). The seasonal expansion of the anchovy distribution to the Teuri seabird foraging area might be important rather than overall abundance of this Tsushima anchovy stock, which was measured in the southern areas of the Japan Sea. In years when the local availability of epipelagic fish (anchovy and sandlance) was low, JCOM fed on benthic and epibenthic fishes in coastal areas 30 to $40 \mathrm{~km}$ from the colony, and, hence, their feeding frequency was reduced (Watanuki et al. 2004), ultimately affecting chick growth and survival (Kato et al. 2001). Similar to RHAU, breeding success of JCOM was greater in years when warm waters arrived earlier, i.e. high local anchovy availability. An- chovy stock size had no significant relationship with this species either. The local annual catch of $0+$ sandlance (important prey of JCOM; Table 1) positively affected breeding success, also indicating the importance of the availability of this prey.

Why the breeding success of RHAU and JCOM was higher in years when they bred earlier, as reported in common murre Uria aalge in the North Sea (Votier et al. 2009) and cassin's auklet and common murre in California (Schroeder et al. 2009), is unclear. RHAU and JCOM feed on different prey during the pre-laying, laying, and chick-rearing periods (Kato et al. 2001, Ito et al. 2009, M. Ito unpubl. data), yet both species showed an inverse relationship between timing and success. The effects of SST on prey availability could differ between spring (egg laying) and summer (chick rearing). With simple regression analyses, no annual trends were observed in the breeding success of JCOM, though positive effects of year on it (Table 4) could be related to interannual trends in prey availability and timing of breeding.

No climate factors or prey availability indices explained the large interannual variations in the breeding success of BTGL. The gulls fed mostly on sandlance (Fig. 2d). As found in the North Sea (Furness \& Tasker 2000), BTGL that feed mainly on sandlance might be sensitive to changes in the availability of sandlance, but the catch of $0+$ sandlance was not correlated with their breeding success. The potential impact by feral cats on nesting BTGL (Watanuki 2010) might make it difficult to detect the climate factors and prey availability that are associated with their breeding performance.

In regions where seabirds feed mainly on sandlance, climate factors have affected their breeding success through bottom-up effects (Aebischer et al. 1990, Frederiksen et al. 2006). In our region, however, variability of local chl a concentration did not relate to the availability indices of local seabird prey (krill and $0+$ sandlance), the proportion of these prey in the diet, or the seabird timing of breeding. Rather, interannual change in the availability of anchovy, an important alternative prey to sandlance, that appeared to be driven by the warm TC seemed to be important in this area. Alternatively, chl a could be a poor indicator of the abundance of availability of forage fish prey.

\section{CONCLUSIONS}

Interannual variations in broad-scale atmospheric indices, the $\mathrm{AO}$ and the Aleutian Low (manifested as 
the PDO), are linked to winter wind stress and the summer flow rates of the TC (Minobe et al. 2004, present study), respectively. These factors influence the chick diets and breeding performance of 2 species of seabirds in northern Japan Sea, but not a third that may be responding, mainly, to terrestrially based factors (invasive cats). In this area the seasonal range expansion of warm waters and anchovy plays a key role in driving chick diet and breeding performance of seabirds. Our study indicates that the mechanisms of response from climate to seabirds are specific to the regional ecosystem under study as well as variation in the life histories of the seabirds under consideration.

Acknowledgements. We thank A. Kato, Y. Niizuma, A. Takahashi, A. Hayashi, K. Iseki, M. Chochi, M. Kuroki, H. Ishikawa, T. Kagami, M. Takenaka, T. Deguchi, K. Matsumoto, D. Ochi, Y. Manabe, Y. Tanaka, N. Tomita, M. Takagi, H. Nomura, O. Hasegawa, Y. Chin, A. Saito, R. Komatsu, T. Hirotsu, S. Hikosaka, Y. Inoue, R. Fukushima, T. Nakano, Y. Kitahara, and M. Shikata for field assistance; and M. Aotsuka and Y. Kusakabe for their hospitality on the island. Three anonymous reviewers gave critical and useful comments, and W. Sydeman helped by editing the English.

\section{LITERATURE CITED}

Aebischer NJ, Coulson JC, Colebrook JM (1990) Parallel long-term trends across four marine trophic levels and weather. Nature 347:753-755

Anderson PJ, Piatt JF (1999) Community reorganization in the Gulf of Alaska following ocean climate regime shift. Mar Ecol Prog Ser 189:117-123

Barbraud C, Weimerskirch H (2006) Antarctic birds breed later in response to climate change. Proc Natl Acad Sci USA 103:6248-6251

- Bertram DF, Mackas DL, McKinnell SM (2001) The seasonal cycle revisited: interannual variation and ecosystem consequences. Prog Oceanogr 49:283-307

Burnham KP, Anderson DR (1998) Model selection and inference: a practical information-theoretic approach. Springer, New York, NY

Chiba S, Saino T (2003) Variation in mesozooplankton community structure in the Japan/East Sea (1991-1999) with possible influence of the ENSO scale climatic variability. Prog Oceanogr 57:317-339

> Chiba S, Hirota Y, Hasegawa S, Saino T (2005) North-South contrasts in decadal scale variations in lower trophiclevel ecosystems in the Japan Sea. Fish Oceanogr 14: 401-412

> Chochi M, Niizuma Y, Takagi M (2002) Sexual differences in the external measurements of black-tailed gulls breeding on Rishiri Island, Japan. Ornitholog Sci 1: 163-166

> Deguchi T, Watanuki Y, Niizuma Y, Nakata A (2004) Interannual variations of the occurrence of epipelagic fish in the diets of the seabirds breeding on Teuri Island, northern Hokkaido, Japan. Prog Oceanogr 61:267-275

> Durant JM, Anker-Nilssen T, Hjermann DO, Stenseth NC (2004) Regime shift in the breeding of an Atlantic puffin population. Ecol Lett 7:388-394
Durant JM, Hjermann DO, Anker-Nilssen T, Beaugrand G, Mysterud A, Pettorelli N, Stenseth NC (2005) Timing and abundance as key mechanisms affecting trophic interactions in variable environments. Ecol Lett 8:952-958

> Frederiksen M, Harris MP, Daunt F, Rothery P, Wanless S (2004) Scale-dependent climate signals drive breeding phenology of three seabird species. Glob Change Biol 10:1214-1221

> Frederiksen M, Edwards M, Richardson AJ, Halliday NC, Wanless S (2006) From plankton to top predators: bottom-up control of a marine food web across four trophic levels. J Anim Ecol 75:1259-1268

Frederiksen M, Edwards M, Mavor RA, Wanless S (2007) Regional and annual variation in black-legged kittiwake breeding productivity is related to sea surface temperature. Mar Ecol Prog Ser 350:137-143

> Furness RW, Tasker ML (2000) Seabird-fishery interactions: quantifying the sensitivity of seabirds to reductions in sandeel abundance, and identification of key areas for sensitive seabirds in the North Sea. Mar Ecol Prog Ser 202:253-264

Gaston AJ, Jones IL (1998) The auks. Oxford University Press, Oxford

Gaston AJ, Gilchrist HG, Mallory ML, Smith PA (2009) Changes in seasonal events, peak food availability, and consequent breeding adjustment in a marine bird: a case of progressive mismatching. Condor 111:111-119

Grémillet D, Lewis S, Drapeau L, van Der Lingen CD and others (2008) Spatial match-mismatch in the Benguela upwelling zone: Should we expect chlorophyll and seasurface temperature to predict marine predator distribution? J Appl Ecol 45:610-621

- Hanamura Y, Kotori M, Hamada S (1989) Daytime surface swarms of the euphausiid Thysanoessa inermis off the west coast of Hokkaido, northern Japan. Mar Biol 102: 369-376

> Hase H, Yoon JH, Koterayama W (1999) The current structure of the Tsushima warm current along the Japanese coast. J Oceanogr 55:217-235

Hoshino N, Takashima T, Watanobe M, Fujioka T (2009) Age-structures and catch fluctuations of arabesque greenling (Pleurogrammus azonus) in the coastal area of southern Hokkaido, Japan. Sci Rep Hokkaido Fish Exp Stn 76:1-11

Ishikawa K, Watanuki Y (2002) Sex and individual differences in foraging behavior of Japanese cormorants in years of different prey availability. J Ethol 20:49-54

> Ito M, Minami H, Tanaka Y, Watanuki Y (2009) Intra- and inter-annual oceanographic changes as inferred from the diet of a piscivorous seabird. Mar Ecol Prog Ser 393: 273-284

Jenouvrier S, Caswell H, Barbraud C, Holland M, Stroeve J, Weimerskirch H (2009) Demographic models and IPCC climate projections predict the decline of an emperor penguin population. Proc Natl Acad Sci USA 106:1844-1847

Kato A, Watanuki Y, Naito Y (2001) Foraging and breeding performance of Japanese cormorants in relation to prey. Ecol Res 16:745-758

Kato A, Watanuki Y, Naito Y (2003) Foraging behaviour of chick-rearing rhinoceros auklets at Teuri Island, Japan, determined by acceleration-depth recording micro data loggers. J Avian Biol 34:282-287

> Kitaysky AS, Golubova EF (2000) Climate change causes contrasting trends in reproductive performance of planktivorous and piscivorous alcids. J Anim Ecol 69:248-262 
Kuroki M, Kato A, Watanuki Y, Takahashi A (1998) Artificial nest boxes for the study of breeding ecology of rhinoceros auklets Cerorhinca monocerata. J Yamashina Inst Ornithol 30:40-46 (in Japanese with English abstract)

Kuroki M, Kato A, Watanuki Y, Niizuma Y, Takahashi A, Naito Y (2003) Diving behavior of an epipelagically feeding alcid, the rhinoceros auklet (Cerorhinca monocerata). Can J Zool 81:1249-1256

Loeb V, Siegel V, Holm-Hansen O, Hewitt R, Fraser W, Trivelpiece W, Trovelpiece S (1997) Effects of sea-ice extent and krill or salp dominance on the Antarctic food web. Nature 387:897-900

Mihara Y (1998) Distribution of the Japanese anchovy, Engraulis japonicus, off southeastern Hokkaido. Sci Rep Hokkaido Fish Exp Stn 53:9-14 (in Japanese with English abstract)

Minami T (1995) Spawning season of pleuronectid flatfishes in the coastal waters of Hokkaido, Japan (review). Bull Hokkaido Natl Fish Res Inst 59:69-80

> Minobe S, Sako A, Nakamura M (2004) Interannual to interdecadal variability in the Japan Sea based on a new gridded upper water temperature dataset. J Phys Oceanogr 34:2382-2397

Moe B, Stempniewicz L, Jakubas D, Angelier F and others (2009) Climate change and phenological responses of two seabird species breeding in the high-Arctic. Mar Ecol Prog Ser 393:235-246

Nagasawa K, Torisawa M (1991) Fish and marine invertebrates of Hokkaido: biology and fisheries. Kita-nihon Kaiyo Center, Sapporo (in Japanese)

Nelson JB (2005) Pelicans, cormorants, and their relatives. Pelecaniformes. Oxford University Press, Oxford

> Niizuma Y, Takagi M, Senda M, Chochi M, Watanuki Y (2005) Incubation capacity limits maximum clutch size in black-tailed gulls Larus crassirostris. J Avian Biol 36: 421-427

Olssen KM, Larsson H (2004) Gulls of North America, Europe and Asia. Princeton University Press, Princeton

Osa Y, Watanuki Y (2002) Status of seabirds breeding in Hokkaido. J Yamashina Inst Ornithol 33:107-141

> Pinaud D, Weimerskirch H (2002) Ultimate and proximate factors affecting the breeding performance of marine top predator. Oikos 99:141-150

Schreiber EA (2002) Climate and weather effects on seabirds. In: Schreiber EA, Burger J (eds) Biology of marine birds. CRC Press, Boca Raton, FL, p 179-215

Schroeder ID, Sydeman WJ, Sarkar N, Thompson SA, Bograd SJ, Schwing FB (2009) Winter pre-conditioning of seabird phenology in the California Current. Mar Ecol Prog Ser 393:211-223

Slater L, Byrd GV (2009) Status, trends, and patterns of covariation of breeding seabirds at St Lazaria Island, southeast Alaska, 1994-2006. J Biogeogr 36:465-475

Takahashi A, Kuroki M, Niizuma Y, Kato A, Saito A, Watanuki Y (2001) Importance of the Japanese anchovy
Engraulis japonicus to breeding rhinoceros auklets Cerorhinca monocerata on Teuri Island, Sea of Japan. Mar Biol 139:361-371

> Takasuka A, Oozeki Y, Kubota H, Lluch-Cota SE (2008) Contrasting spawning temperature optima: Why are anchovy and sardine regime shifts synchronous across the North Pacific? Prog Oceanogr 77:225-232

> Thayer JA, Sydeman WJ (2007) Spatio-temporal variability in prey harvest and reproductive ecology of a piscivorous seabird, Cerorhinca monocerata, in an upwelling system. Mar Ecol Prog Ser 329:253-265

- Tian Y, Kidokoro H, Watanabe T, Iguchi N (2008) The late 1980s regime shift in the ecosystem of Tsushima warm current in the Japan/East Sea: evidence from historical data and possible mechanisms. Prog Oceanogr 77: $127-145$

Tomita N, Niizuma Y, Takagi M, Ito M, Watanuki Y (2009) Effect of interannual variations in sea-surface temperature on egg-laying parameters of black-tailed gulls (Larus crassirostris) at Teuri Island, Japan. Ecol Res 24: 157-162

> Votier SC, Hatchwell BJ, Mears M, Birkhead TR (2009) Changes in the timing of egg-laying of a colonial seabird in relation to population size and environmental condition. Mar Ecol Prog Ser 393:225-233

Wanless S, Harris MP, Lewis S, Frederiksen M, Murray S (2008) Later breeding in northern gannets in the eastern Atlantic. Mar Ecol Prog Ser 370:263-269

Watanabe Y, Zenitani H, Kimura R (1995) Population decline of the Japanese sardine Sardinops melanosticutus owing to recruitment failures. Can J Fish Aquat Sci 52: 1609-1616

Watanuki Y (1987a) Breeding biology and foods of rhinoceros auklets on Teuri Island, Japan. Proc NIPR Symp Polar Biol 1:175-183

Watanuki Y (1987b) Inter-species, inter- and intra-colony differences in food habits and breeding of Larus gulls. PhD thesis, Hokkaido University, Hakodate (in Japanese)

Watanuki Y (2010) Cat, human and seabirds on Teuri Island. Nature of Teuri Island 31:1-2 (in Japanese)

Watanuki Y, Kato A, Naito Y (1996) Diving performance of male and female Japanese cormorants. Can J Zool 74: 1098-1109

Watanuki Y, Ishikawa K, Takahashi A, Kato A (2004) Foraging behavior of a generalist marine top predator, Japanese cormorants, in years of demersal vs. epipelagic prey. Mar Biol 145:427-434

Watanuki Y, Ito M, Deguchi T, Minobe S (2009) Climateforced seasonal mismatch between the hatching of rhinoceros auklets and the availability of anchovy. Mar Ecol Prog Ser 393:259-271

> Yeh SW, Park YG, Min H, Kim CH, Lee JH (2010) Analysis of characteristics in the sea surface temperature variability in the East/Japan Sea. Prog Oceanogr 85:213-223 